\title{
Del acoso escolar y sus consecuencias
}

MIGUEL ÁNGEL HEREDIA GARCíA

Presidente de la Fundación Piquer

Artículo recibido: 07/01/10; evaluado: 15/05/10 - 07/06/10; aceptado: 16/07/10

"Comportamiento prolongado de insulto verbal, rechazo social, intimidación psicológica y agresividad fisica de unos niños hacia otros que se convierten, de esta forma, en víctimas de sus compañeros" (Olweus).

El problema de la violencia (acosol que se produce en el entorno escolar se inscribe en un espectro mucho más amplio: el fenómeno social (afecta a las relacionas humanas) y psicológico (afecta a personas que se enfrentan a estas situaciones) de la violencia que se da en la calle, en la vida doméstica, en el ámbito económico, político... porque no es sino un reflejo de ello. Y todos son víctimas y responsables: los agresores, agredidos y (también) los espectadores.

Ante estas situaciones, algunas víctimas del maltrato de sus iguales, terminan reaccionando aprendiendo que la única manera de sobrevivir es convertirse, a su vez, en violentos (La mejor defensa es un buen ataquel y desarrollar actitudes maltratadoras hacia otros. Los violentos, frente a la indefensión de la víctima y la actitud pasiva de los espectadores, actúan reforzando sus actitudes abusivas, trasladando estos comportamientos a otras situaciones sociales, encontrando siempre una justificación a sus actos de provocación o acoso, desde era una broma, hasta la típica me estaba molestando: en este entorno, siempre busca -y encuentra la complicidad de otros, logrando, en muchas ocasiones, la tolerancia de los adultos. El agresor transgrede las normas, crecido en la fuerza moral que le otorga el privilegio de saltarse todo lo impuesto, que a su vez le proporciona cierto prestigio social y una no menor degradada autoimagen de seguridad, ganada a golpes de fuerza y poder. Ello degenera en un deterioro encubierto de su desarrollo moral, acercándose a una conducta precriminal. Asimismo, los espectadores valoran el fenómeno de la violencia como algo grave y frecuente, pero el miedo difuso conlleva ser objeto de violencia, algo muy negativo desde el punto vista psicológico y moral. Se aprende a no involucrarse, a pasar por alto los actos injustos y a callar ante el dolor ajeno. Aquí nadie sale impune.

Y en estas estamos, en las perniciosas consecuencias que para todos reviste el fenómeno. Las investigaciones apuntan a que el abuso y la victimización siempre conllevan efectos a largo plazo y requieren la actuación inmediata de la Comunidad Escolar, la construcción de unas generaciones jóvenes más sanas y justas, porque no hay que olvidar que el núcleo de socialización primera se produce, junto con la familia, en la escuela: si un niño o niña es obligado a sentir la victimización se siente afectada su imagen personal y su identidad. En el otro lado, la imagen que se configura respecto al agresor es la de la 
permisividad y la impunidad, con lo que se fragmenta cualquier aspecto positivo de una personalidad apta para socializar. En todo caso, está claro que la violencia provoca consecuencias negativas para todos, agravadas por un entorno de tolerancia, factor añadido que contribuye a aumentar el riesgo de daño psicológico en todos los participantes. Se ha demostrado que el grupo de iguales representa un círculo cerrado, ocultan esta realidad a profesores, padres y adultos; los propios compañeros, a través de la "ley del silencio", bloquea su denuncia, agrava los hechos y tolera sus consecuencias.

Para las víctimas resulta trágico ser el objeto del abuso, lo que provoca el deterioro personal y académico, llegando a instalarse un autoconcepto de debilidad social con escasa capacidad para afrontar las relaciones interpersonales, produciendo un aislamiento cada vez mayor, que afectará gravemente no sólo a su capacidad socializadora, sino también a su propio rendimiento académico e intelectual.

También aquí se produce el juego del traspaso de la patata caliente,: los padres culpabilizan a los centros escolares, estos a los padres, ambos a las instituciones, todos a los medios de comunicación y, en general, a la sociedad. Pero, ¿quién asume las responsabilidades? De nuevo una llamada a la reflexión y la actuación de toda (digo toda) la Comunidad Educativa.

maheredia@piquerestudios.com 